\title{
Climatic and other responses to the Lakagígar 1783 and Tambora 1815 volcanic eruptions in the Czech Lands
}

RUDOLF BRÁZDIL ${ }^{1,2}$, LADISLAVA ŘEZNÍČKOVÁ ${ }^{1,2}$, HUBERT VALÁŠEK ${ }^{\dagger}$, LUKÁŠ DOLÁK ${ }^{1,2}$, OLDŘICH KOTYZA ${ }^{3}$

\footnotetext{
${ }^{1}$ Masaryk University, Faculty of Sciences, Institute of Geography, Brno, Czechia; e-mail: brazdil@ sci.muni.cz, ladkar@sci.muni.cz, dolak@sci.muni.cz

${ }^{2}$ Global Change Research Institute, Czech Academy of Sciences, Brno, Czechia

${ }^{3}$ Regional Museum, Litoměřice, Czechia; e-mail: muzeum.ltm@telecom.cz
}

ABSTRACT Using documentary data and long-term temperature and precipitation series for the years 1775-2007, climatic, weather and other phenomena in the Czech Lands following the 1783 Lakagígar eruption in Iceland and the 1815 Tambora eruption in Indonesia are investigated. The Lakagígar eruption had clear post-volcanic effects on the weather in central Europe (dry fog, heavy thunderstorms, optical phenomena), with the occurrence of significant cold temperature anomalies in winter 1783/84, spring 1785 and the summer and autumn of 1786 . The Tambora eruption was not accompanied by any particular weather phenomena, but was followed by an extremely cold summer in 1816. A comparison of the two eruptions shows that the effects of the Lakagígar eruption were climatologically stronger than those of the Tambora eruption.

KEY WORDS Lakagígar eruption - Tambora eruption - climatic effects - human impacts - Czech Lands

BRÁzDIL, R., ŘEZNíčKovÁ, L., VALÁŠEK, H., DOLÁK, L., KOTYZA, O. (2017): Climatic and other responses to the Lakagígar 1783 and Tambora 1815 volcanic eruptions in the Czech Lands. Geografie, 122, 2, 147-168.

Received May 2016, accepted October 2016.

CC Česká geografická společnost, z. s., 2017 


\section{Introduction}

It is generally accepted that volcanic particles injected into the atmosphere during volcanic eruptions influence the radiative balance, a process expressed in summer temperature decreases for up to three years afterwards. This is particularly clear on a global scale after large, tropical volcanic eruptions (Sear et al. 1987; Bradley 1988; Robock, Mao 1995; Briffa et al. 1998; Robock 2000; Jones et al. 2004; Písek, Brázdil 2006; Timmreck 2012; Lacis 2015; LeGrande, Anchukaitis 2015; Sigl et al. 2015). Dynamic effects on atmospheric circulation, expressed as one or two post-volcanic mild winters in the Northern Hemisphere are another response to eruptions (Robock 2000; Fischer et al. 2007). The effects of volcanic eruptions on precipitation appear less frequently in the literature (e.g. Gillett et al. 2004; Fischer et al. 2007; Wegmann et al. 2014).

Among the numerous papers analysing various aspects of the climatic effects of volcanic eruptions, considerable attention has been dedicated to the Lakagígar (Laki) eruption of 1783 in Iceland which started on 8 June 1783, when a fissure opened up along the Laki crater-row. By February 1784, this had been followed by the largest terrestrial lava flow in the last millennium (Thordarson, Self 1993, 2003; Stevenson et al. 2003). Moreover, Mt. Asama in Japan erupted at the beginning of August 1783 (Aramaki 1956, 1957; Zielinski et al. 1994; Demarée, Mikami 2005). Both eruptions have been classified in terms of Volcanic Explosivity Index (VEI) at a rating of 4 (Newhall, Self 1982).

The Lakagígar eruption was associated with high mortality in western Europe (Grattan et al. 2003, 2005; Witham, Oppenheimer 2005). Brázdil, Valášek, Macková (2003) addressed the 1783 Lakagígar eruption, describing a number of extreme post-volcanic climatic anomalies (see also Písek, Brázdil 2006). Vasold (2004) reported on summer 1783, followed by a severe winter and disastrous flood in February 1784, in Germany. Brázdil et al. (2010) described extreme floods in Europe following the first, very severe, winter after the eruption (1783/1784). Trigo, Vaquero, Stothers (2010) examined the impacts of the Lakagígar eruption on the Southern Hemisphere.

The volcanic eruption of Tambora (Lesser Sunda Islands, Indonesia) on 10 April 1815 attracted even more attention. Classified at rating 7 on the Volcanic Explosivity Index (Newhall, Self 1982), this is among the most powerful of its kind ever recorded. It threw around $60 \mathrm{Tg}$ of $\mathrm{SO}_{2}$ into the stratosphere, where the $\mathrm{SO}_{2}$ oxidized to sulphate aerosols (Self et al. 2004; Kandlbauer, Sparks 2014). The year of 1816, characterized as the "Year without a Summer", became grim testimonial to the Tambora eruption (see e.g. Stommel, Stommel 1983; Stothers 1984; Harington 1992; Vupputuri 1992; Oppenheimer 2003; Klingaman, Klingaman 2013; Luterbacher, Pfister 2015). A large number of further studies addressing the Tambora effects on various spatial scales exist (e.g., Briffa, Jones 1992; Habegger 1997; Písek, 
Brázdil 2006; Kužić 2007; Trigo et al. 2009; Lee, MacKenzie 2010; Bodenmann et al. 2011; Auchmann et al. 2012; Brugnara et al. 2015).

The aim of this paper is analyse differences in climatic and environmental patterns following the Lakagígar eruption, weaker and closer to the Czech Lands territory, and the Tambora eruptions, significantly stronger, but at a far greater distance. The data employed for this analysis are described in Section 2 and the methods applied in Section 3. Section 4 addresses the climatic and environmental impacts of the immediately post-eruption years, including perceptions of these events and extreme climate. The discussion in Section 5 concentrates on the climatic effects of the two eruptions in the long-term, as well as on societal consequences. Section 6 provides some concluding remarks.

\section{Data}

Two temperature and one precipitation series were selected to cover the time in which the two volcanic eruptions took place in the same climatological series:

1. monthly and seasonal temperature series recorded at the Prague-Klementinum station (1775-2010), homogenised by Brázdil et al. (2012)

2. monthly and seasonal temperature series for central Europe (1501-2007) reconstructed from series of temperature indices for Germany, Switzerland and Czechia (the Czech Lands; 1501-1854) and from homogeneous temperature series taken at 11 meteorological stations in these countries and Austria (1760-2007) by Dobrovolný et al. (2010)

3. seasonal precipitation series for the Czech Lands (Czechia; 1501-2010), reconstructed from precipitation indices for the Czech Lands (1501-1854) and mean Czech precipitation series (1804-2010; Brázdil et al. 2012) by Dobrovolný et al. (2015).

Because the above central European temperature series ends in 2007, the other series mentioned above are used only until that year.

A broad range of documentary evidence from the Czech Lands is used for description of weather patterns and related phenomena, drawn from various chronicles, weather diaries, early meteorological observations and newspapers. Such data are part of the historico-climatological database complied and held by the Institute of Geography, Masaryk University, Brno. Cereal price data are taken from published series in Schebek (1873), Albert (1964), Tlapák (1977) and Brázdil, Durd'áková (2000). 


\section{Methods}

All documentary data refer to primary sources critically evaluated with respect to their origin, historical reliability, temporal distance from the events described, exact dating, content analysis and interpretation of phenomena in terms of recent meteorological knowledge. Much of the information is of a qualitative character. Some of these sources have already been published elsewhere (e.g. Brázdil et al. $2003,2007)$ or have been used in more broadly-based studies.

The three climatological series employed (see Section 2) are considered in terms of anomalies from a 1961-1990 reference period with respect to comparison with more recent climatic patterns. A composite approach is taken to mutual comparison: the years of eruption, i.e. 1783 and 1815 are used as the base. To describe climatic, weather and other phenomena possibly related to the two volcanic eruptions, particular attention is devoted to the post-volcanic years, with the data based on documentary and instrumental records. For the long-term context, the eruption year and three subsequent years are characterised by their order and magnitude in the whole series shown in order of increasing (temperatures) or decreasing (precipitation).

\section{Results}

\subsection{Climate in the post-volcanic years}

Figure 1 shows a composite of seasonal temperature anomalies for the PragueKlementinum station and central European series expressed as anomalies with respect to the 1961-1990 reference period. The Lakagígar eruption was followed by a slightly warmer summer (1783), followed by negative seasonal temperature anomalies until the end of 1786. Noteworthy as particularly cold were the winters of 1783/1784 and 1784/1785, spring 1785 and autumn 1786 (with quite a cold summer for 1786 at Prague-Klementinum). In terms of individual months, March 1785 was the coldest, followed by the winter months of $1783 / 84$, October 1784, February and April 1785 (Fig. 2). The series of cold seasons after the Tambora eruption, lasting until 1818, was interrupted only by a milder winter in 1816/1817 (Fig. 1); temperature anomalies were also slightly positive in the following winter, and spring 1818. Particularly April 1817, October 1817 and December 1815, but also July 1815 and 1816 and November 1815 were among the coldest months (Fig. 2). High positive anomalies occurred only in January and February 1817.

Compared to those of temperatures, seasonal precipitation anomalies, based on series for the Czech Lands, were more variable (Fig. 1). A particularly dry autumn in 1783, a dry summer in 1784 and a wet winter in 1783/1784, with wet summers for 1785 and 1786, were prominent after the Lakagígar eruption. Outstandingly 
high summer totals followed the Tambora eruption in 1815, while a drier autumn in 1815 and a wetter summer in 1816 were notable among the other seasons.

\subsection{Peculiarities of post-volcanic weather}

The Lakagígar eruption had clear responses in the observed weather, marked by the presence of dry fog, unusual optical phenomena and heavy thunderstorms. The
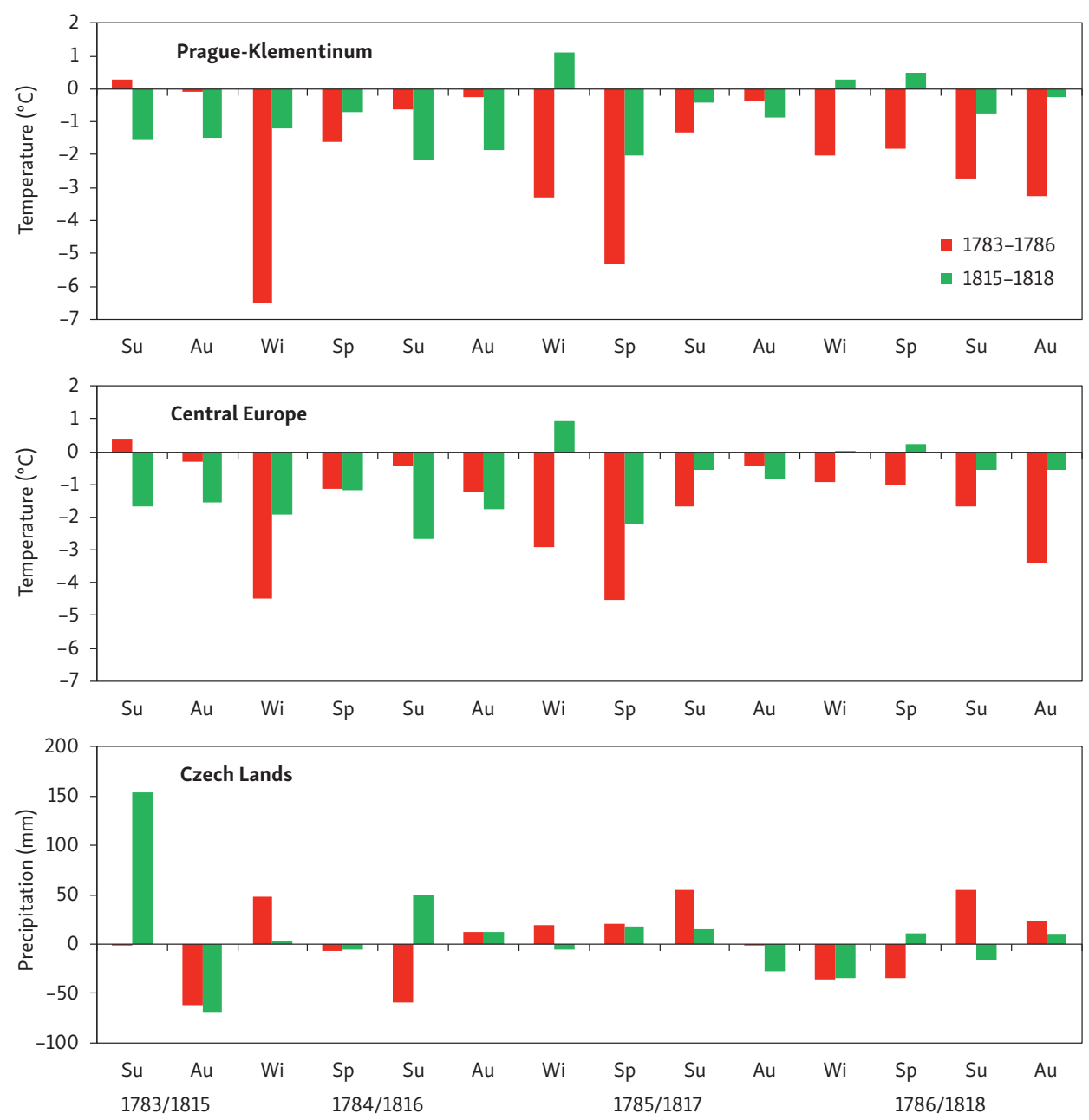

Fig. 1 - Composite of seasonal temperature anomalies at the Prague-Klementinum station and central Europe and seasonal precipitation anomalies in the Czech Lands in 1783-1786 and 1815-1818 (1961-1990 reference period; Wi - DJF, Sp - MAM, Su - JJA, Au - SON). 
dry fog (in modern meteorological terminology it corresponds to haze - Sobíšek 1993) in central Europe was first observed on 16 June 1783 in Germany and western Bohemia (Stothers 1996) as well as at Prague-Klementinum, where it occurred in 11 days of June, in 24 days of July and in 7 days in August 1783 (Strnadt 1785). Visual daily weather observations kept by Reverend Karel Bernard Hein in Hodonice report fog from 27 June to 1 July and then in a further 12 days of July (Brázdil, Valášek, Macková 2003). Fog smelling of sulphur is reported from 18 June to 18 July, together with thunderstorms without rain, at Noviny pod Ralskem (Wiechowsky 1928).

Jiří Vrbas from Písečné (Paměti starých písmáků moravských 1916) also described optical phenomena in addition to dry fog: "In 1783, every day and night from the festival of St. John [24 June] to the harvest, there were such dense fogs everywhere that nothing could be seen beyond a tiny piece of the world. The sun and the moon changed. The sun rose blood-red every day and the moon was like a black sack." Many reports also describe peculiar colours of the sun or moon at rising and setting. In Prague, a red sun (moon) is reported for 19 days from June to September (also four days with aurora borealis; Poznámky 1977). A report from the chronicle of Antonín Kodytek from Kunvald (Nezbeda, Šula 1970) adds: "[...] in summer there was such heat that had there not been unusual fog that shaded the sun, everything might have been burnt by the sun's heat. [...] the rising sun could not be seen due to fires and then
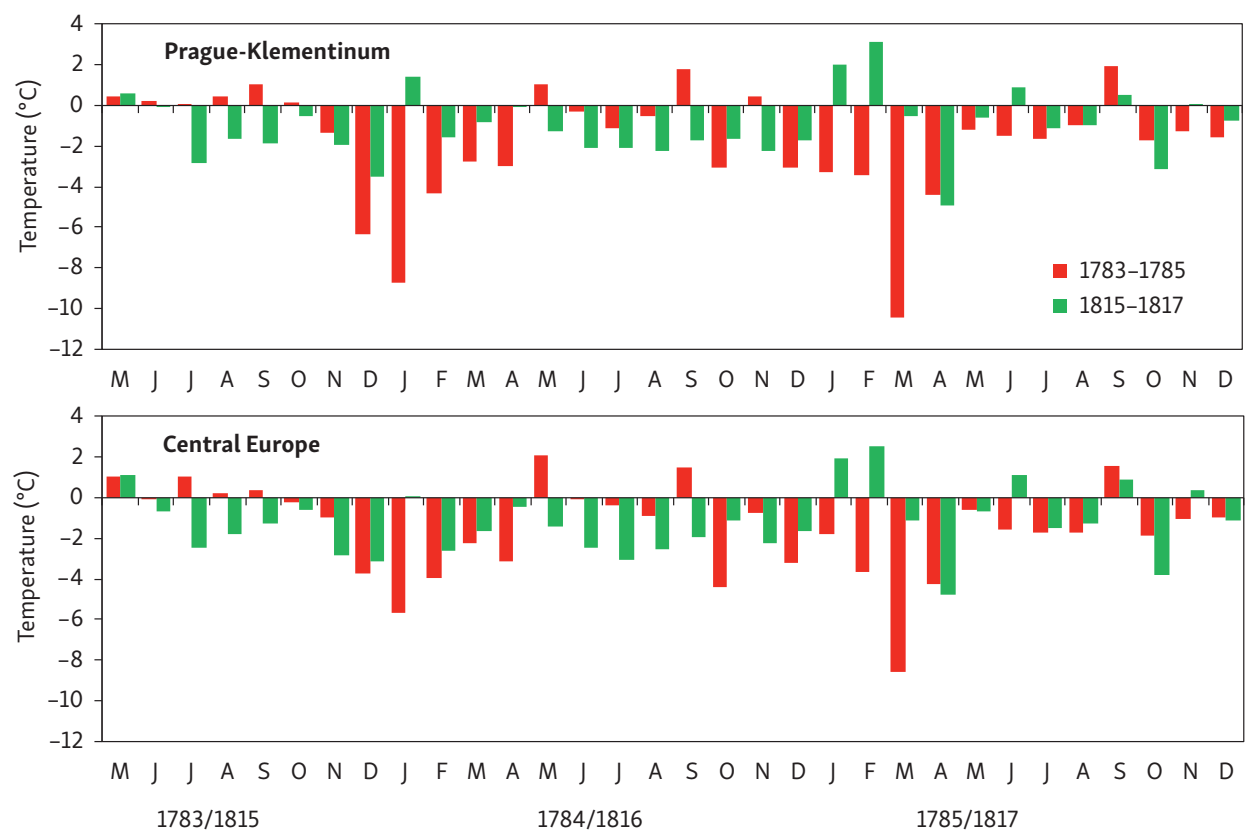

Fig. 2 - Composite of monthly temperature anomalies (with respect to 1961-1990 reference period) at Prague-Klementinum and in central Europe in 1783-1785 and 1815-1817. 
from six to nine o'clock [it] looked like a red-hot iron ball, then from nine to three or four oclock it shone more intensely, but looked sad, which people held in awe."

Heavy thunderstorms, often without rain, also attracted considerable attention. For example, Hein records 17 days with thunderstorms in summer 1783, the highest number during his observations in the 1780s (Brázdil, Valášek, Macková 2003). Systematic meteorological observations at Prague-Klementinum report thunderstorms on 23 days (Strnadt 1785). Among the heavy thunderstorms of summer 1783, an event on 29 June in Klatovy stands out. For example, the chronicle of the Šebesta family (Hostaš 1895) says: “[...] there started such a downpour that it was as if water were poured out of a bucket [and], at the same time there was such a thunder and storm uninterrupted from one o'clock in the afternoon until the evening and the lightning struck more than a hundred times." The lightning set fire to the armoury and its gunpowder. The resulting explosion killed or injured several people and damaged buildings in the surroundings. Six people were killed while ringing town bells, a practice commonly held at the time to avert thunderstorms, on 4 July in Doubrava, while other human casualties were reported in Litoměřice, Terezín and Roudnice nad Labem (for more details see Brázdil, Valášek, Macková 2003; Soukupová 2013). These fatalities probably contributed to an imperial ban on ringing bells against thunderstorms, decreed on 26 November 1783 (Pán 1931).

An example of the comprehensive nature of some of the descriptions of the weather effects after the volcanic event may be found in the chronicle of the Fuchs family from Třebětice (Verbík 1982): "For the entire summer of 1783 there were big, dense fogs with some [kind of] stench arising out of them, and thunder was heard but no clouds were visible. In the morning, during sunrise, the sun was as red as blood and this continued for a long time. And in the afternoon again, towards evening, it was the same. There was great drought in this year, constant thunder but no rain."

After the Tambora eruption, no indication appeared in running meteorological observations or reported documentary evidence (cf. Poznámky 1977; S1, S2, S3) of weather phenomena comparable with those immediately after Lakagígar. In this context, only a report of "the sun as if covered by veil" in the daily weather observations of Reverend Šimon Hausner from Buchlovice (for 6 days between 20 January and 14 March 1816 and 5 days between 16 December 1816 and 28 February 1817, further 16 June 1817; on 3 March 1817 he also used this comparison for the light of the moon) seems notable. For 11 days, between 31 January and 23 June 1816, Hausner described the afternoon sunshine as "bland" or "gloomy" (S4).

\subsection{Other events and phenomena in post-volcanic years}

The occurrence of significant flooding is one of the interesting phenomena of the post-Lakagígar years. Particularly notable was a disastrous flood in central Europe 
as February turned to March 1784, after the very severe and snowy winter of 1783/1784 (Brázdil et al. 2010). A flood on the River Vltava at Prague arising out of snowmelt and ice movement, culminating on 28 February 1784, was accompanied by loss of life and extensive damage. Floods were also recorded for many places on the Elbe and Ohře rivers in Bohemia. Ice movement also contributed to a Vltava flood on 16-17 April 1785, which lasted for ten days, following the coldest March in Prague temperature observations (from 1775 to the present). Another Vltava flood, on 17 August 1786 at Prague, was due to continuous rainy weather since 7 August; it left fields flooded and bridges destroyed (Brázdil et al. 2003, 2005). All three floods were also reported by documentary sources for the River Dyje in southern Moravia (Brázdil, Kirchner, eds. 2007).

In the post-Tambora years, rainy weather in July-early August 1815 led to the flood, documented on the Elbe by Kreybich's records at Žitenice for 10-14 August (S1) and at Litoměřice for 9 August with duration of eight days (Katzerowsky 1895). In Prague, the River Vltava flooded on 9-10 August (Brázdil et al. 2005). In particular, damage to agricultural crops in flooded fields is reported. A further flood on the River Vltava is documented for 7 March 1817 (Brázdil et al. 2005).

Also worthy of note in the post-Tambora years are reports of five landslides in north-western Bohemia, recorded by Kreybich. He dated four of them to spring 1817: (i) Kř́žžová hora Mt. north of Žitenice, (ii) Trojhora Hill between Chudoslavice and Třebušín, (iii) Vitín near Malé Březno (community now defunct), and (iv) east of Jílové (S3). He mentioned a fifth landslide at Bohyně (east of Jílové) at the end of November (S3). These five landslides are not included in the historical catalogue of landslides by Špůrek (1972).

Meteorological conditions in the post-Tambora times were unfavourable to yields of agricultural crops, as a number of Czech documentary sources record. Haymaking and the grain harvest were negatively influenced by rainy weather in 1815 (moreover, the wheat and some of the rye were infected with rust - see $\mathrm{S} 1$ ). The quality and quantity of the grape harvest were also below average (Katzerowsky 1895), there was no fruit at all, and the potato yield was bad (Bachmann 1911). In 1816, documentary sources report cold and wet patterns reflected in bad harvests and rising prices for all products. For example, Václav Jan Mašek of Řenče wrote: "All the grain was saturated, it was too wet to dig the potatoes and from this [situation] it followed that the yield was bad, prices rose to terribly high levels and hunger [became apparent]" (Urban 1999). In Buchlovice, Šimon Hausner noted for July that people were driven by poverty to start the harvest early; the harvest continued for a long time (S4). Further low grain yields and delayed sowing in the autumn complicated the situation (S5; Paměti starých písmáků moravských 1916). A shortage of grain resulted in a decree banning the distillation of spirits, issued on 13 November (Kreuzinger 1862). Oats and grain had to be imported from Silesia (S6). Flour made of barley, oats, vetch, peas, potatoes and acorns began to be added 

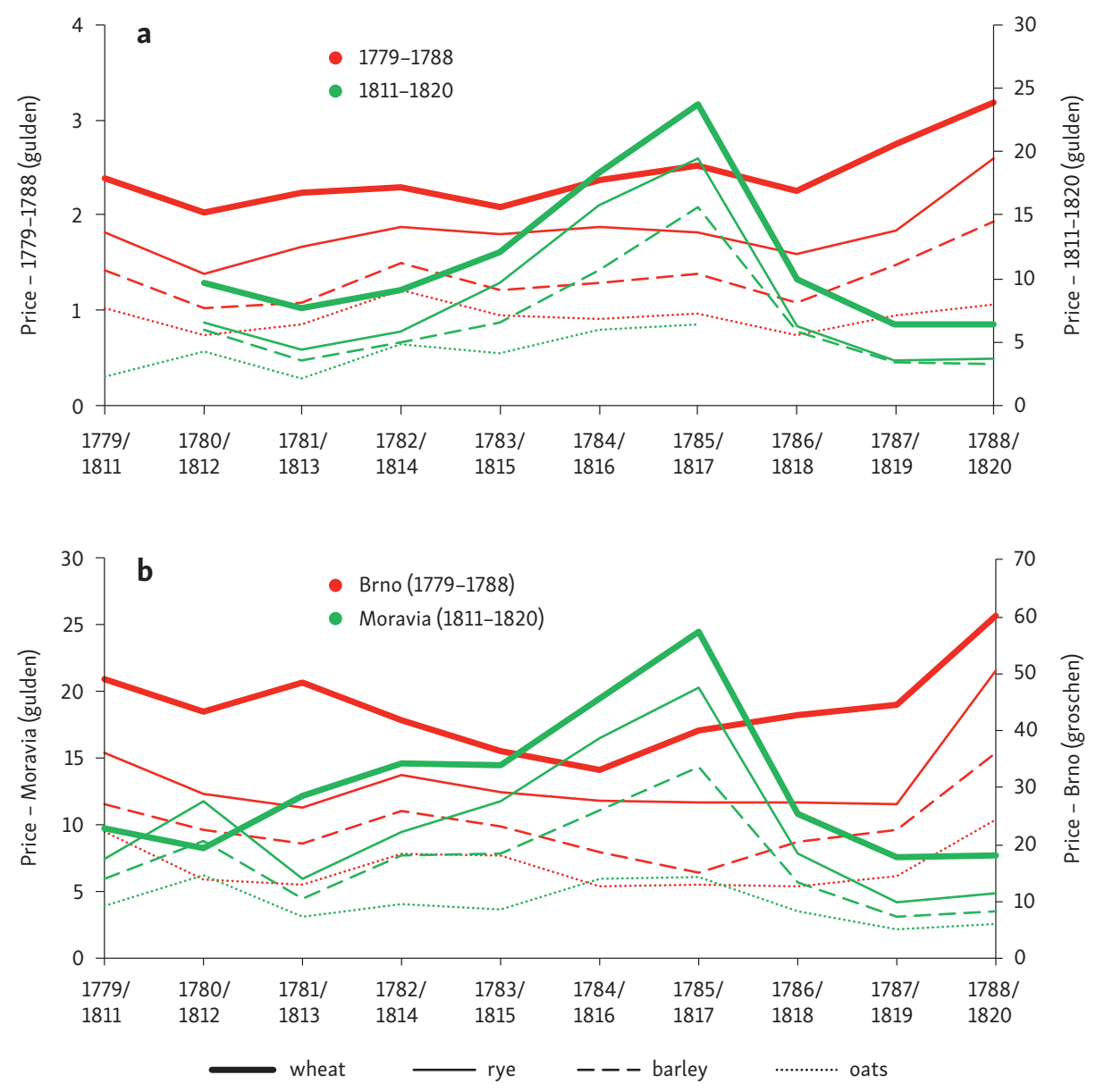

Fig. 3 - Composite of fluctuations in the prices of the four main cereals (wheat, rye, barley, oats) in the 1779-1788 and 1811-1820 periods: a - Prague (data from Schebek 1873), Litoměřice for oats (gulden / 61.49 l) - data only up to 1817 from Tlapák (1977); b - Brno (groschen) - data from Brázdil, Durdáková (2000), Moravia (gulden/hl) - data from Albert (1964).

to bread mixes (Robek 1974). In his annual summary for 1816, Hausner remarks succinctly: "Hunger is inevitable." (S4) The situation culminated in severe shortages of goods (so bad, for example, that people milled rotting oats for flour - Trnka 1912) and rising prices in 1817. A chronicle from Velká Bystřice also reports insufficient money to buy grain and a far higher number of beggars as than ever before (Roubic 1987). The high prices continued until the good harvest of 1817 (when a very good potato yield was reported for Boskovice, for example - S5).

Figure 3 shows the quantitative changes in mean prices of basic grain crops for Prague (Schebek, ed. 1873) and Moravia (Albert 1964). A continuous increase 
from 1813 accelerated sharply in 1815-1816 and peaked in 1817. In Prague, prices rose c. 4.5-fold for rye and barley and tripled for wheat (for grain price changes in many Bohemian towns see Tlapák 1977), while in Moravia equivalent grain prices tripled. Oat prices tripled in Litoměřice and doubled in Moravia. After the good harvest of 1817, prices fell to 1813 levels or less.

A composite of grain prices for Prague and Brno around the Lakagígar time shows none of the dramatic trends described above for the post-Tambora years (Fig. 3). The prices of rye, barley and oats in Bohemia generally decreased from 1782 to 1786, while wheat rose slightly from 1783 to 1785 , but dropped in the following year. Similar tendencies to those in Prague also appeared in Brno, to the east, with a shift \pm 1 year. A significant increase in cereal prices began in Bohemia from 1786 and in Brno a year later. Aside from inflation, this could be attributed to the compulsory supply of grain to military stores, used to feed the military in transit and on long-term station, leading to grain shortages (Petráň 1977). According to František Jan Vavák, such movements took place in Bohemia in the years 1786 and 1788 in particular (Skopec 1910, 1912).

\section{Discussion}

\subsection{Long-term climatic context of Lakagígar and Tambora eruptions}

The climatic effects of the Lakagígar and Tambora eruptions, which both belong to the last part of so-called Little Ice Age (Wanner 2000; Matthews, Briffa 2005), may also be compared from the long-term viewpoint by ordering the mean seasonal temperatures in increasing series of seasonal values over the 1775-2007 period (Table 1a). Prague-Klementinum demonstrates the more extreme patterns post-Lakagígar: the coldest spring in 1785 and coldest summer in 1786, with the second-coldest autumn in 1786 and the third-coldest winter in 1783/1784. Among the seasons following the Tambora eruption, only summer 1816 stands out, as the fifth-coldest (summer 1815 was $11^{\text {th }}$-coldest, tied with three other years). Central European temperature series averaging data over a broader area agree with Prague for spring 1785 and autumn 1786, but disclose summer 1816, post-Tambora, as absolutely the coldest in the 1775-2007 period. Furthermore, the general central European view significantly weakens the position of the cold summer of 1786 and enhances that of the cold summer of 1785 and spring 1817 compared with Prague. This reveals that spatial averaging of data and moving the territorial area of interest south-west of Prague (where the majority of the stations used for calculation of the central European series are located) may strengthen the summer signal of volcanic eruptions, including large tropical eruptions. While extremely cold springs, summers and autumns express clearly after both eruptions, the two cold 
Table 1 - (a) Mean seasonal temperatures at Prague-Klementinum and in central Europe series, in order of increasing values (from coldest to warmest), and (b) of seasonal precipitation in the Czech Lands, in order of decreasing values (from wettest to driest), for the years after the Lakagigar (1783-1786) and Tambora (1815-1818) eruptions. The period used for all three series is 1775-2007 (233 years)

(a)

\begin{tabular}{|c|c|c|c|c|c|c|c|c|}
\hline \multirow[t]{2}{*}{ Year } & \multicolumn{4}{|c|}{ Prague-Klementinum } & \multicolumn{4}{|c|}{ Central Europe } \\
\hline & Winter & Spring & Summer & Autumn & Winter & Spring & Summer & Autumn \\
\hline \multicolumn{9}{|c|}{ Lakagígar eruption } \\
\hline 1783 & - & - & $147-157$ & $131-145$ & - & - & $164-173$ & $130-137$ \\
\hline 1784 & 3 & $39-44$ & $74-81$ & $125-127$ & $7-8$ & $59-64$ & $98-100$ & $61-67$ \\
\hline 1785 & $22-23$ & 1 & $20-27$ & $117-124$ & $24-25$ & 1 & $9-12$ & $124-129$ \\
\hline 1786 & $59-60$ & $24-30$ & 1 & 2 & $100-104$ & $65-70$ & $9-12$ & 2 \\
\hline \multicolumn{9}{|c|}{ Tambora eruption } \\
\hline 1815 & - & $187-193$ & $11-14$ & $36-45$ & - & $198-201$ & $9-12$ & $36-40$ \\
\hline 1816 & $90-91$ & $92-98$ & 5 & $21-26$ & $60-63$ & $46-58$ & 1 & $29-32$ \\
\hline 1817 & $181-184$ & $16-18$ & $93-107$ & $71-79$ & $183-190$ & $8-9$ & $73-84$ & $89-97$ \\
\hline 1818 & $146-150$ & $172-175$ & $66-73$ & $125-127$ & $142-148$ & $149-156$ & $73-84$ & $107-116$ \\
\hline
\end{tabular}

(b)

\begin{tabular}{lcccc}
\hline Year & Winter & Spring & Summer & Autumn \\
\hline Lakagígar eruption & & & & \\
\hline 1783 & - & $156-160$ & $122-124$ & 228 \\
1784 & $16-17$ & $113-117$ & $208-212$ & $80-86$ \\
1785 & $55-59$ & $42-43$ & $24-27$ & $120-126$ \\
1786 & $205-207$ & $195-198$ & $24-27$ & $56-60$ \\
\hline Tambora eruption & & & & \\
\hline 1815 & - & 191 & 1 & 229 \\
1816 & $102-109$ & $108-111$ & $33-34$ & $77-79$ \\
1817 & $130-131$ & $50-54$ & $93-95$ & $191-194$ \\
1818 & $202-203$ & $71-73$ & $150-151$ & $91-95$ \\
\hline
\end{tabular}

winters after Lakagígar have no equivalent after the Tambora event. However, winter 1816/1817 could be classified as milder, corresponding with expectations (compare Robock 2000; Fischer et al. 2007).

Precipitation totals in the post-volcanic years were less extreme (Table $1 \mathrm{~b}$ ) than those for temperatures. In the series for the Czech Lands in the entire 1775-2007 period, only summer 1815 was the wettest and autumn 1815 the fifth-driest. After the Lakagígar eruption, only winter 1783/1784 fell into the top 10 per cent of wettest winters $\left(16^{\text {th }}-17^{\text {th }}\right.$ in the order), while autumn 1783 was the sixth-driest.

In terms of individual months, those following the Lakagígar eruption appear among the ten coldest years seven times in the two series and those following 
Tambora four times (cf. Fig. 2). The coldest months to appear in both complete series were March 1785 and April 1816; the coldest at Prague-Klementinum alone was July 1786. The second-coldest in the Prague series appear in January 1784 and August 1786, while this position is occupied in the central European series by April 1785 (in the Prague series, April 1785 is third) and October 1784. Among the ten coldest years were also July 1815 (Prague-Klementinum only), July 1816 (central Europe only), August 1816 and October 1817 (both series).

\subsection{Explanations of post-volcanic weather and climatic anomalies}

The clearly-observable and unusual weather effects such as dry fog, optical phenomena and heavy thunderstorms without rain after the Lakagígar eruption (cf. Section 4.2) stimulated a large body of discussion. For example, the chronicler Johann Josef Langer from Rýmařov attributed them to an earthquake in Messina (Italy) on 5 February 1783 (Tutsch 1914): "During the following summer [1783], outstanding fogs were observed in the European countries, here one time, there the next, also in the surroundings. The cause of the fog was attributed to this [Messina] earthquake." News of the eruption, brought by vessels of the Danish trading monopoly from Iceland to Copenhagen, did not reach Europe until 1 September. Benjamin Franklin (1706-1790), American diplomat, scientist, inventor and writer, tried as early as May 1784 to explain the dry fog observed in the summer months of 1783 and the severe winter of $1783 / 1784$ as follows: "... or whether it was the vast quantity of smoke, long continuing to issue during the summer from Hecla, in Iceland, and that other volcano which arose out of the sea near that island, which smoke might be spread by various winds over the northern part of the world, is yet to ascertain" (Humphreys 1913). A year later he was probably the first to connect climate with volcanic eruptions (Demarée, Ogilvie 2001). Observations on the Asama eruption were published by the Dutchman Isaac Titsingh in Dejima (Nagasaki) in the early $19^{\text {th }}$ century (Demarée et al. 2013).

Attempts to explain climatic anomalies around the time of the Tambora eruption were stimulated by the series of cold summers from 1812 onwards, after a warm summer in 1811. First, a certain Böckmann, in an article published in Badischen Staatszeitung and reprinted in the Wiener Zeitung (9 July 1816, p. 755) and the Brünner Zeitung (12 July 1816, pp. 759-760), linked them to Flaugergues' comet (the "Great Comet" observed in autumn 1811), the number of sunspots or a longterm, slow cooling of the Earth ( $c f$. Brázdil et al. 2016). The second half of April 1817 was extremely cold and snowy; for example, Šimon Hausner in Buchlovice reported such awful weather that "almost no previous April [since 1803] has been as bad" (S4). In search of explanations, Wiener Zeitung (8 May 1817, p. 421), covering a report of the I. R. Astronomical Observatory [k. k. Sternwarte] in Vienna, suggested 
earthquakes and volcanic eruptions as possible reasons for cooling. Some contemporary scientists also considered huge masses of ice drifting in the North Atlantic as responsible for the cold summer of 1816 in western Europe (Bodenmann et al. 2011). A relation between the "Year without a Summer" and the Tambora eruption was pointed out by Humphreys (1913) in a discussion of the role of volcanic dust and other factors in climatic changes.

\subsection{Social impacts of the Lakagigar and Tambora eruptions}

Section 4.3 indicates that the negligible social impacts of the Lakagígar eruption were simply not comparable with the severe aftermath of Tambora. For example, Post (1977) classified the post-Tambora time as "the last great subsistence crisis in the Western world", following on from the period of the Napoleonic wars in Europe. The famines documented in some central European countries such as Germany (Bayer 1966) and Switzerland (Krämer 2015) are widely-known, for example. These were associated with enormous rises in grain prices, attributed by Post (1970) not only to inflation and overproduction, but also to low temperatures and abundant precipitation in 1816-1817 related to volcanic eruptions, particularly Tambora (an unidentified tropical eruption in late November / early December 1808 was classified as the second most explosive sulphur-dioxide-rich volcanic eruption for the previous two centuries - Guevara-Murua et al. 2014). The subsequent drop in prices then led to a series of bankruptcies, poverty and vagrancy; this situation was reflected in population decline and increased mortality. In contrast to Post (1970), Albert (1964), investigating an agricultural crisis after 1817 in Moravia, did not associate the less productive years with the Tambora eruption. He attributed the increase in grain prices after the Napoleonic wars to a shift in agricultural emphasis, especially towards potato cultivation. Potatoes began to compete with grain, while low livestock numbers were insufficient to absorb any corn surplus. The good harvests in 1818-1821 then contributed to a decrease in grain prices in Moravia after 1817.

The social impacts of the Lakagígar and Tambora eruptions in the Czech Lands must be addressed in the light of the contemporary socio-political situation. Emperor Joseph II, considered by many a representative of enlightened absolutism, ruled the Austrian Empire in the 1780s. His reign was notable for new freedoms - the abolition of serfdom, the beginnings of religious tolerance and the restriction of censorship. It was also a time of German cultural colonisation ("Germanization"), burgeoning bureaucracy and state centralization. The Czech Lands saw something of a national renaissance, cultural development (new schools, theatres, libraries, etc.) and economic advancement (establishment of the first factories, construction of imperial roads, etc.; Bělina, Kaše, Kučera 2001). 
Much of society in the Czech Lands was agricultural, centring on grain production; however, innovations to backward agricultural practices were slow to penetrate (Beranová, Kubačák 2010). By end of this period, there was growing dissatisfaction throughout society, largely fuelled by rising prices and despotic approaches to the implementation of change (Lněničková 1999).

In the second decade of the $19^{\text {th }}$ century, the Czech Lands played a leading part in the Austrian Empire's participation in the industrial revolution. Craftsmanship and manufacturing gathered pace, and agriculture took to the rotation of crops. The Napoleonic wars, accompanied by stagnation of population growth, rising prices, poverty, hunger, increasing numbers of beggars and a high incidence of unrest in the countryside led to state bankruptcy in 1811 (Bělina, Hlavačka, Tinková 2013). Under Emperor Franz I, a deeply conservative ruler, royal power expanded to penetrate every corner of society, contributing to the creation of what was essentially a police state, characterised by stifling bureaucracy, censorship and resistance to reform (Taylor 1998). A growing demand for grain and foodstuffs, with rising prices, contributed to higher incomes for farmers and an agricultural boom in the Czech Lands that lasted until 1817 (Lněničková 1999).

\section{Conclusions}

The main features of the Lakagígar and Tambora eruptions and post-volcanic climatic patterns and environmental and socio-economic effects in the Czech Lands can be summarised in following points:

1. Temperature patterns: Lakagígar - a number of extreme seasons in 1784-1786; Tambora - one extreme summer 1816 ("Year without a Summer")

2. Precipitation patterns: Lakagígar - extreme autumn 1783; Tambora - extreme summer 1815 and autumn 1815

3. Weather effects: Lakagígar - dry fog (haze), heavy thunderstorms (no rain), sun and moon red; Tambora - no directly observed post-volcanic weather effects

4. Environmental effects: Lakagígar - floods in February 1784, April 1785 and August 1786, no indications of landslides; Tambora - floods in August 1815 and March 1817, five landslides in north-western Bohemia in 1817

5. Socio-economic effects: Lakagígar - no effects on agriculture and grain prices, no crisis indications, fatalities among those ringing city bells to ward off thunderstorms - prohibition of ringing; Tambora - bad grain harvest, rise in grain prices, lack of bread, hunger, high vagrancy, important societal impacts.

In evaluation and interpretation of these basic results we have to take in account the fact, that extreme phenomena like volcanic eruptions contribute to some environmental (natural) or social-economic changes in complicated cascades or 
chains of processes and phenomena with various relaxation times. While for the post-volcanic weather and climatic patterns are these relationships to eruptions more straightforwarded (see points 1-3 of conclusions), in case of environmental (point 4) or socio-economic (point 5) effects such relations are much more complicated. Particularly in case of landslides (point 4), although they are generally related to higher precipitation, the occurrence of five landslides in north-western Bohemia during 1817 cannot be taken as any prove of Tambora volcanic effect.

The detail regional analysis of post-volcanic consequences for the Czech Lands, presented in this contribution, extends existing knowledge of effects of both eruptions in the European and worldwide scales (cf. e.g. Stothers 1984, 1996; Harington 1992; Grattan et al. 2003, 2005; Oppenheimer 2003; Vasold 2004; Demarée, Mikami 2005; Písek, Brázdil 2006; Trigo et al. 2009, 2010; Bodenmann et al. 2011; Auchmann et al. 2012; Brugnara et al. 2015; Krämer 2015; Luterbacher, Pfister 2015).

From the summary comparison of the consequences of both eruptions follows that the effects of the high-latitude Lakagígar eruption (VEI =4, closer to central Europe) were climatologically stronger than those of the tropical Tambora eruption (VEI = 7, a far greater distance from central Europe), while the opposite held for societal responses. The analyses and documentation cited in this paper demonstrate the relatively weaker effects of large tropical eruptions at regional or local scales for the Czech Lands (central Europe - cf. e.g. Briffa, Jones 1992; Písek, Brázdil 2006) compared with certain closer but less intense eruptions, such as the Lakagígar eruption in Iceland in 1783-1784. This is also in accordance with the results of Mikšovský et al. (2014), who disclosed the prominent and statistically significant imprint of major volcanic events on the global temperature signal while changes in mean Czech temperature series remained negligible (1866-2010 period).

\section{References}

ALBERT, E. (1964): Vliv první kapitalistické agrární krize XIX. století na moravské zemědělství (The influence on Moravian agriculture of the first capitalist agrarian crisis of the $19^{\text {th }}$ century). Acta Universitatis Agriculturae A, 1964, 1, 165-180.

ARAMAKI, S. (1956): The 1783 activity of Asama volcano. Part I. Japanese Journal of Geology and Geography, 27, 189-229.

ARAMAKI, S. (1957): The 1783 activity of Asama volcano. Part II. Japanese Journal of Geology and Geography, 28, 11-33.

AUCHMANN, R., BRÖNNIMANN, S., BREDA, L., BÜHLER, M., SPADIN, R., STICKLER, A. (2012): Extreme climate, not extreme weather: the summer 1816 in Geneva, Switzerland. Climate of the Past, 8, 325-335.

BACHMANN, J. (1911): Aufzeichnungen eines Alt-Leitmeritzers. Mitteilungen des Vereines für Geschichte der Deutschen in Böhmen, 50, 107-131, 254-281.

BAYER, D. (1966): O gib mir Brot. Die Hungerjahre 1816 und 1817 in Württemberg und Baden. Deutsches Brotmuseum e.V., Ulm/Donau. 
BERANOVÁ, M., KUBAČÁK, A. (2010): Dějiny zemědělství v Čechách a na Moravě (A History of Agriculture in Bohemia and Moravia). Libri, Praha.

BĚLINA, P., HLAVAČKA, M., TINKOVÁ, D. (2013): Velké dějiny zemí Koruny české. Svazek XI.a, 1792-1860 (The Great History of the Countries of the Czech Crown, Volume XIa, 1792-1860). Paseka, Praha.

BĚLINA, P., KAŠE, J., KUČERA, J.P. (2001): Velké dějiny zemí Koruny české. Svazek X., 1740-1792 (The Great History of the Countries of the Czech Crown, Volume X, 1740-1792). Paseka, Praha.

BODENMANN, T., BRÖNNIMANN, S., HADORN, G.H., KRÜGER, T., WEISSERT, H. (2011): Perceiving, explaining, and observing climatic changes: An historical case study of the "year without a summer" 1816. Meteorologische Zeitschrift, 20, 577-587.

BRADLEY, R.S. (1988): The explosive volcanic eruption signal in Northern Hemisphere continental temperature records. Climatic Change, 12, 221-243.

BRÁZDIL, R., BĚLÍNOVÁ, M., DOBROVOLNÝ, P., MIKŠOVSKÝ, J., PIŠOFT, P., ŘEZNÍČKOVÁ, L., ŠTĚPÁNEK, P., VALÁŠEK, H., ZAHRADNÍČEK, P. (2012): Temperature and Precipitation Fluctuations in the Czech Lands During the Instrumental Period. Masaryk University, Brno.

BRÁZDIL, R., DEMARÉE, G.R., DEUTSCH, M., GARNIER, E., KISS, A., LUTERBACHER, J., MACDONALD, N., ROHR, C., DOBROVOLNÝ, P., KOLÁř, P., CHROMÁ, K. (2010): European floods during the winter 1783/1784: scenarios of an extreme event during the 'Little Ice Age'. Theoretical and Applied Climatology, 100, 163-189.

BRÁZDIL, R., DOBROVOLNÝ, P., ELLEDER, L., KAKOS, V., KOTYZA, O., KVĚTOŇ, V., MACKOVÁ, J., MÜLLER, M., ŠTEKL, J., TOLASZ, R., VALÁŠEK, H. (2005): Historické a současné povodně v České republice (Historical and Recent Floods in the Czech Republic). Masarykova univerzita, Český hydrometeorologický ústav, Brno, Praha.

BRÁZDIL, R., DURĎÁKOVÁ, M. (2000): The effect of weather factors on fluctuations of grain prices in the Czech Lands in the $16^{\text {th }}-18^{\text {th }}$ centuries. Prace Geograficzne, 108, 19-25.

BRÁZDIL, R., KIRCHNER, K., eds. (2007): Vybrané přírodní extrémy a jejich dopady na Moravě a ve Slezsku (Selected Natural Extremes and Their Impacts in Moravia and Silesia). Masarykova univerzita, Český hydrometeorologický ústav, Ústav geoniky Akademie věd České republiky, v.v.i., Brno, Praha, Ostrava.

BRÁZDIL, R., ŘEZNÍČKOVÁ, L., VALÁŠEK, H., DOLÁK, L., KOTYZA, O. (2016): Climatic effects and impacts of the 1815 eruption of Mount Tambora in the Czech Lands. Climate of the Past, 12, 1361-1374.

BRÁZDIL, R., ŘEZNÍČKOVÁ, L., VALÁŠEK, H., KOTYZA, O. (2007): Early instrumental meteorological observations in the Czech Lands III: František Jindřich Jakub Kreybich, Žitenice, 1787-1829. Meteorologický časopis, 10, 63-74.

BRÁZDIL, R., VALÁŠEK, H., MACKOVÁ, J. (2003): Climate in the Czech Lands during the 1780 s in light of the daily weather records of parson Karel Bernard Hein of Hodonice (southwestern Moravia): Comparison of documentary and instrumental data. Climatic Change, 60, 297-327.

BRIFFA, K.R., JONES, P.D. (1992): The climate of Europe during the 1810s with special reference to 1816. In: Harington, C.R. (ed.): The Year Without a Summer? World Climate in 1816. Canadian Museum of Nature, Ottawa, 372-391.

BRIFFA, K., JONES, P.D., SCHWEINGRUBER, F., OSBORN, T. (1998): Influence of volcanic eruptions on Northern Hemisphere summer temperature over the past 600 years. Nature, $393,450-455$. 
BRUGNARA, Y., AUCHMANN, R., BRÖNNIMANN, S., ALLAN, R.J., AUER, I., BARRIENDOS, M., BERGSTRÖM, A., BHEND, J., BRÁZDIL, R., COMPO, G.P., CORNES, R.C., DOMINGUEZ-CASTRO, F., VAN ENGELEN, A.F.V., FILIPIAK, J., HOLOPAINEN, J., JOURDAIN, S., KUNZ, M., LUTERBACHER, J., MAUGERI, M., MERCALLI, L., MOBERG, A., MOCK, C.J., PICHARD, G., ŘEZNÍČKOVÁ, L., VAN DER SCHRIER, G., SLONOSKY, V., USTRNUL, Z., VALENTE, M.A., WYPYCH, A., YIN, X. (2015): A collection of sub-daily pressure and temperature observations for the early instrumental period with a focus on the "year without a summer" 1816. Climate of the Past, 11, 1027-1047.

DEMARÉE, G., MIKAMI, T. (2005): Climatic impacts of Lakagígar (Iceland) and Asama (Japan) volcanic eruptions in the year 1783 (in Japanese). Chikyo Monthly, 27, 687-692.

DEMARÉE, G., MIKAMI, T., TSUKAHARA, T., ZAIKI, M. (2013): In the Wake of “De Liefde" The Instrumental Meteorological Observations of the Vereenigde Oost-Indische Compagnie (VOC). Bulletin des Séances Académie Royale des Sciences d'Outre-Mer, 59, 385-405.

DEMARÉE, G.R., OGILVIE, A.E.J. (2001): Bons Baisers d'Islande: Climatic, environmental, and human dimensions impacts of the Lakagígar eruption (1783-1784) in Iceland. In: Jones, P.D., Ogilvie, A.E.J., Davies, T.D., Briffa, K.R. (eds.): History and Climate. Memories of the Future. Kluwer Academic / Plenum Publishers, New York, Boston, Dordrecht, London, Moscow, 219-246.

DOBROVOLNÝ, P., BRÁZDIL, R., TRNKA, M., KOTYZA, O., VALÁŠEK, H. (2015): Precipitation reconstruction for the Czech Lands, AD 1501-2010. International Journal of Climatology, $35,1-14$.

DOBROVOLNÝ, P., MOBERG, A., BRÁZDIL, R., PFISTER, C., GLASER, R., WILSON, R., VAN ENGELEN, A., LIMANÓWKA, D., KISS, A., HALÍČKOVÁ, M., MACKOVÁ, J., RIEMANN, D., LUTERBACHER, J., BÖHM, R. (2010): Monthly and seasonal temperature reconstructions for Central Europe derived from documentary evidence and instrumental records since AD 1500. Climatic Change, 101, 69-107.

FISCHER, E.M., LUTERBACHER, J., ZORITA, E., TETT, S.F.B., CASTY, C., WANNER, H. (2007): European climate response to tropical volcanic eruptions over the last half millennium. Geophysical Research Letters, 34, L05707.

GILLETT, N.P., WEAVER, A.J., ZWIERS, F.W., WEHNER, M.F. (2004): Detection of volcanic influence on global precipitation. Geophysical Research Letters, 31, L12217.

GRATTAN, J.P., DURAND, M., TAYLOR, S. (2003): Illness and elevated human mortality in Europe coincident with the Laki fissure eruption. In: Oppenheimer, C., Pyle, D.M., Barclay, J. (eds.): Volcanic Degassing. Geological Society, London, 410-414.

GRATTAN, J., RABARTIN, R., SELF, S., THORDARSON, T. (2005): Volcanic air pollution and mortality in France 1783-1784. Comptes Rendus Geoscience, 337, 641-651.

GUEVARA-MURUA, A., WILLIAMS, C.A., HENDY, E.J., RUST, A.C., CASHMAN, K.V. (2014): Observations of a stratospheric aerosol veil from a tropical volcanic eruption in December 1808: is this the Unknown 1809 eruption? Climate of the Past, 10, 1707-1722.

HABEGGER, D.L. (1997): 1816 - The year without a summer. Mennonite Family History, 16, 19-23.

HARINGTON, C.R., ed. (1992): The Year Without a Summer? World Climate in 1816. Canadian Museum of Nature, Ottawa.

HOSTAŠ, K. (1895): Pamětní zápisy Klatovské rodiny Šebestovy (Memorial records of the Šebesta family from Klatovy). Šumavan, 28, 348.

HUMPHREYS, W. J. (1913): Volcanic dust and other factors in the production of climatic changes, and their possible relation to Ice Ages. Journal of the Franklin Institute, 176, 131-172.

JONES, P.D., MOBERG, A., OSBORN, T.J., BRIFFA, K.R. (2004): Surface climate responses to explosive volcanic eruptions seen in long European temperature records and mid-to-high 
latitude tree-ring density around the Northern Hemisphere. In: Robock, A., Oppenheimer, C. (eds.): Volcanism and Earth's Atmosphere. Geophysical Monograph Series, 139. AGU, Washington, D.C., 239-254.

KANDLBAUER, J., SPARKS, R.S.J. (2014): New estimates of the 1815 Tambora eruption volume. Journal of Volcanology and Geothermal Research, 286, 93-100.

KATZEROWSKY, W. (1895): Meteorologische Nachrichten aus den Archiven der Stadt Leitmeritz. Im Selbstverlage des Verfassers, Leitmeritz.

KLINGAMAN, W.K., KLINGAMAN, N.P. (2013): The Year Without Summer: 1816 and the Volcano that Darkened the World and Changed History. St. Martin's Griffin, New York.

KRÄMER, D. (2015): “Menschen grasten mit dem Vieh”. Die letzte grosse Hungerkrise der Schweiz 1816/1817. Wirtschafts-, Sozial- und Umweltgeschichte (WSU), 4. Schwabe Verlag, Basel.

KREUZINGER, E. (1862): Chronik der alten und neuern Zeit Troppau's, oder Troppau und seine Merkwürdigkeiten. Im Selbstverlage des Herausgebers, Troppau.

KUŽIĆ, K. (2007): The effect of two volcano eruptions on the Croatian lands at the beginning of the $19^{\text {th }}$ century. Hrvatski meteorološki časopis, 42, 15-39.

LACIS, A. (2015): Volcanic aerosol radiative properties. Past Global Changes Magazine, 23, 50-51.

LEE, D.S., MACKENZIE, A.R. (2010): Trans-hemispheric effects of large volcanic eruptions as recorded by an early $19^{\text {th }}$ century diary. International Journal of Climatology, 30, 2217-2228.

LEGRANDE, A.N., ANCHUKAITIS, K.J. (2015): Volcanic eruptions and climate. Past Global Changes Magazine, 23, 46-47.

LNĚNIČKOVÁ, J. (1999): České země v době předbřeznové: 1792-1848 (The Czech Lands Before the Time of March: 1792-1848). Libri, Praha.

LUTERBACHER, J., PFISTER, C. (2015): The year without a summer. Nature Geoscience, 8, 246-248.

MATTHEWS, J.A., BRIFFA, K.R. (2005): The 'Little Ice Age': Re-evaluation of an evolving concept. Geografiska Annaler, 87A, 17-36.

MIKŠOVSKÝ, J., BRÁZDIL, R., ŠTĚPÁNEK, P., ZAHRADNÍČEK, P., PIŠOFT, P. (2014): Longterm variability of temperature and precipitation in the Czech Lands: an attribution analysis. Climatic Change, 125, 253-264.

NEWHALL, C.G., SELF, S. (1982): The Volcanic Explosivity Index (VEI): An estimate of explosive magnitude for historical volcanism. Journal of Geophysical Research, 87, 1231-1238.

NEZBEDA, V., ŠŮLA, J. (1970): Kunvaldská kronika Antonína Kodytka 1740-1786 (The Chronicle of Kunvald by Antonín Kodytek 1740-1786). Nákladem Orlického muzea, Choceň.

OPPENHEIMER, C. (2003): Climatic, environmental and human consequences of the largest known historic eruption: Tambora volcano (Indonesia) 1815. Progress in Physical Geography, 27, 230-259.

Paměti starých písmáků moravských (Memoirs of the Early Moravian Writers). Nákladem Selského archivu, Velké Meziř́íčí, 1916.

PÁN, J. (1931): František Martin Pelcl. Paměti (František Martin Pelcl. Memoirs). Nakladatelství Fr. Borový, Praha.

PETRÁŇ, J. (1977): Ceny obilí a tržní okruhy v Čechách v 18. a počátkem 19. století (Grain prices and market circuits in Bohemia in the $18^{\text {th }}$ century and at the beginning of the $\left.19^{\text {th }}\right)$. AUC Philosophica et historica, Studia historica XVII, 3, 9-49.

PÍSEK, J., BRÁZDIL, R. (2006): Responses of large volcanic eruptions in the instrumental and documentary climatic data over Central Europe. International Journal of Climatology, 26, 439-459.

POST, J.D. (1970): The economic crisis of 1816-1817 and its social and political consequences. The Journal of Economic History, 30, 248-250. 
POST, J.D. (1977): The Last Great Subsistence Crisis in the Western World. The John Hopkins University Press, Baltimore, London.

Poznámky z „Klementinských pozorování 1775-1839“ (Notes from “Klementinum observations 1775-1839”). Hydrometeorologický ústav, Praha, 1977.

ROBEK, A. (1974): Lidové kronikářství na Kralupsku a Mělnicku. Edice lidových kronikářských textů (Folk Chronicle Writing in the Kralupy and Mělník Regions. Folk Chronicle Texts Edition). Ústav pro etnografii a folkloristiku ČSAV, Praha.

ROBOCK, A. (2000): Volcanic eruptions and climate. Review of Geophysics, 38, 191-219.

ROBOCK, A., MAO, J. (1995): The volcanic signal in surface temperature observations. Journal of Climate, 8, 1086-1103.

ROUBIC, A. (1987): Kronika rychtářů Urbaníka a Hořínka z Velké Bystřice z let 1789-1848 (The chronicle of the reeves Urbaník and Hořínek of Velká Bystřice from the years 1789-1848). Okresní archív v Olomouci, Olomouc, 213-238.

SCHEBEK, E., ed. (1873): Die Getreidepreise zu Prag 1655 bis 1872. In: Collectiv-Austellung von Beiträgen zur Geschichte der Preise veranstaltet zur Welt-Ausstellung 1873 Wien von der Handels- und Gewerbekammer in Prag, Katalog. Heinr. Mercy, Prag, 91-104.

SEAR, C.B., KELLY, P.M., JONES, P.D., GOODESS, C.M. (1987): Global surface-temperature responses to major volcanic eruptions. Nature, 330, 365-367.

SELF, S., GERTISSER, R., THORDARSON, T., RAMPINO, M.R., WOLFF, J.A. (2004): Magma volume, volatile emissions, and stratospheric aerosols from the 1815 eruption of Tambora. Geophysical Research Letters, 31, L20608.

SIGL, M., WINSTRUP, M., McCONNELL, J.R., WELTEN, K.C., PLUNKETT, G., LUDLOW, F., BÜNTGEN, U., CAFFEE, M., CHELLMAN, N., DAHL-JENSEN, D., FISCHER, H., KIPFSTUHL, S., KOSTICK, C., MASELLI, O.J., MEKHALDI, F., MULVANEY, R., MUSCHELER, R., PASTERIS, D.R., PILCHER, J.R., SALZER, M., SCHÜPBACH, S., STEFFENSEN, J.P., WINTHER, B.M., WOODRUFF, T.E. (2015): Timing and climate forcing of volcanic eruptions for the past 2,500 years. Nature, 523, 543-549.

SKOPEC, J. (1910): Paměti Františka J. Vaváka, souseda a rychtáře milčického z let 1770-1816. Kniha druhá (Rok 1784-1790). Část I. (1784-1786) [Memoirs of František J. Vavák, inhabitant of the neighbourhood and reeve in Milčice for the years 1770-1816. The second book (1784-1790). Part I (1784-1786)]. Nákladem „Dědictví sv. Jana Nepomuckého“, Praha.

SKOPEC, J. (1912): Paměti Františka J. Vaváka, souseda a rychtáře milčického z let 1770-1816. Kniha druhá (Rok 1784-1790). Část II. (1787-1790) [Memoirs of František J. Vavák, inhabitant of the neighbourhood and reeve in Milčice for the years 1770-1816. The second book (1784-1790). Part II (1787-1790)]. Nákladem „Dědictví sv. Jana Nepomuckého“, Praha.

SOBÍŠEK, B. (1993): Meteorologický slovník výkladový a terminologický (The Explanatory and Terminological Meteorological Vocabulary). Academia, Ministerstvo životního prostředí ČR, Praha.

SOUKUPOVÁ, J. (2013): Heavy storms in 1783 in a historical documentary record. Meteorologický časopis, 16, 11-18.

STEVENSON, D.S., JOHNSON, C.E., HIGHWOOD, E.J., GAUCI, V., COLLINS, W.J., DERWENT, R.G. (2003): Atmospheric impact of the 1783-1784 Laki eruption: Part I Chemistry modeling. Atmospheric Chemistry and Physics, 3, 487-507.

STOMMEL, H., STOMMEL, E. (1983): Volcano Weather: The Story of 1816, The Year without a Summer. Seven Seas Press, Newport, RI.

STOTHERS, R.B. (1984): The great Tambora eruption in 1815 and its aftermath. Science, 224, 1191-1198. 
STOTHERS, R.B. (1996): The great dry fog of 1783. Climatic Change, 32, 79-89.

STRNADT, A. (1785): Betrachtungen über einige meteorologische Gegenstände; besonders über die Ebbe und Fluth in der Luft, als auch über die mehrmaligen täglichen Beobachtungen. Abhandlungen der böhmischen Gesellschaft der Wissenschaften I, Prag.

ŠPŮREK, M. (1972): Historical Catalogue of Slide Phenomena. Studia Geographica 19. Geografický ústav ČSAV, Brno.

TAYLOR, A. (1998): Poslední století habsburské monarchie: Rakousko a Rakousko-Uhersko v letech 1809-1918 (The Last Century of the Hapsburg Monarchy: Austria and Austro-Hungary in the Years 1809-1918). Barrister \& Principal, Brno.

THORDARSON, T., SELF, S. (1993): The Laki (Skaftár Fires) and Grílmsvötn eruptions in 1783-1785. Bulletin of Volcanology, 55, 233-263.

THORDARSON, T., SELF, S. (2003): Atmospheric and environmental effects of the 1783-1784 Laki eruption: a review and reassessment. Journal of Geophysical Research, 108, AAC7-1AAC7-29.

TIMMRECK, C. (2012): Modeling the climatic effects of large explosive volcanic eruptions. WIREs Climate Change, 3, 545-564.

TLAPÁK, J. (1977): Tržní ceny základních druhů obilovin v některých městech ze středních, severních a severovýchodních Čech v letech 1767-1848 (Market prices of basic cereal varieties in a number of towns in northern and north-eastern Bohemia in the years 1767-1848). AUC Philosophica et Historica, 3, 139-192.

TRIGO, R.M., VAQUERO, J.M., ALCOFORADO, M.-J., BARRIENDOS, M., TABORDA, J., GARCÍA-HERRERA, R., LUTERBACHER, J. (2009): Iberia in 1816, the year without a summer. International Journal of Climatology, 29, 99-115.

TRIGO, R.M., VAQUERO, J.M., STOTHERS, R.B. (2010): Witnessing the impact of the 1783-1784 Laki eruption in the Southern Hemisphere. Climatic Change, 99, 535-546.

TRNKA, F. (1912): Kroniky novoměstské. Část II (Chronicles of Nové Město. Part II). Nákladem a tiskem A. Veselého, Nové Město na Moravě.

TUTSCH, F. (1914): Die älteste Chronik Römerstadts und ihr Verfasser. In: XVI. Jahresbericht der Landesoberrealschule zu Römerstadt, Römerstadt, 4-47.

URBAN, J.F. (1999): Písmák jižního Plzeňska Václav Jan Mašek (Václav Jan Mašek, Writer, in the Southern Plzeň Region). Granát, Horní Bříza.

VASOLD, M. (2004): Die Eruptionen des Laki von 1783/84. Ein Beitrag zur deutschen Klimageschichte. Naturwissenschaftliche Rundschau, 57, 602-608.

VERBÍK, A. (1982): Kronika rodiny Fuchsovy (The Chronicle of the Fuchs Family). Blok, Brno.

VUPPUTURI, R.K.R. (1992): The Tambora eruption in 1815 provides a test on possible global climatic and chemical perturbations in the past. Natural Hazards, 5, 1-16.

WANNER, H. (2000): Vom Ende der letzten Eiszeit zum mittelalterlichen Klimaoptimum. In: Wanner, H., Gyalistras, D., Luterbacher, J., Rickli, R., Salvisberg, E., Schmutz, C. (eds.): Klimawandel im Schweizer Alpenraum. Vdf Hochschulverlag AG an der ETH Zürich, Zürich, 73-78.

WEGMANN, M., BRÖNNIMANN, S., BHEND, J., FRANKE, J., FOLINI, D., WILD, M., LUTERBACHER, J. (2014): Volcanic influence on European summer precipitation through monsoons: Possible cause for "Years Without a Summer". Journal of Climate, 27, 3683-3691.

WIECHOWSKY, A. (1928): Aus den Aufzeichnungen des Lehrers Anton Lehmann aus Neuland bei Niemes. Mitteilungen des Nordböhmischen Vereines für Heimatforschung und Wanderpflege, 51, 28-36, 110-115.

WITHAM, C.S., OPPENHEIMER, C. (2005): Mortality in England during the 1783-4 Laki Craters eruption. Bulletin of Volcanology, 67, 15-26. 
ZIELINSKI, G.A., FIACCO, R.J., MAYEWSKI, P.A., MEEKER, L.D., WHITLOW, S., TWICKLER, M.S., GERMANI, M.S., ENDO, K., YASUI, M. (1994): Climatic impact of the A.D. 1783 Asama (Japan) eruption was minimal: Evidence from the GISP2 ice core. Geophysical Research Letters, 21, 2365-2368.

\section{Archival sources}

(S1) Archiv Akademie věd České republiky, Praha, fond Státní hvězdárna, inv. č. 782 (VI C 8, č. 17): Meteorologische Beobachtungen nebst ökonomischen Bemerkungen vom Jahre 1815 in Schüttenitz unweit der K. Kreisstadt Leitmeritz beobachtet von Fr. Jac. H. Kreybich.

(S2) Archiv Akademie věd České republiky, Praha, fond Státní hvězdárna, inv. č. 783 (VI C 8, č. 18): Meteorologische Beobachtungen mit oekonomischen Bemerkungen vom Jahre 1816 beobachtet in Schüttenitz 1/2 Stunde Nordöstlich von der K. Kreisstadt Leitmeritz enfernt von Franz Jacob Heinrich Kreybich.

(S3) Archiv Akademie věd České republiky, Praha, fond Státní hvězdárna, inv. č. 784 (VI C 8, č. 19): Meteorologische Beobachtungen vom Jahre 1817 in Schüttenitz 1/2 Stunde Nordestlich von Leitmeritz beobachtet von Franz Jac. H. Kreybich.

(S4) Moravský zemský archiv, Brno, fond G 138 Rodinný archiv Berchtoldů (1202)1494-1945, inv. č. 851: Denní sledování počasí buchlovským farářem Šimonem Hausnerem 1803-1831.

(S5) Státní okresní archiv Blansko, fond Archiv města Boskovice, inv. č. 109: Kronika Dominika Kučery.

(S6) Státní okresní archiv Česká Lípa, fond Sbírka rukopisů, sign. 13/3: Witterungs-Geschichte. Auszug aus den Titl: Lesenwürdige Sammlungen der hinterlegten Jahrgängen. Von Anton Lehmann Lehrer in Neuland. Abgeschrieben durch Joseph Meißner.

\section{SHRNUTÍ}

\section{Klimatické a další odezvy vulkanických erupcí Lakagígaru z roku 1783 a Tambory z roku 1815 v českých zemích}

Práce se zabývá studiem klimatických, povětrnostních a ostatních jevů v českých zemích následujících po dvou geograficky a velikostně odlišných erupcích v poslední části tzv. malé doby ledové: Lakagígaru na Islandu (Index vulkanické explosivity VEI = 4) dne 8. července 1783 (doplněné začátkem srpna erupcí sopky Asama v Japonsku s VEI = 4) a Tambory v Indonésii (VEI = 7) dne 10. dubna 1815. Klimatologické analýzy se opírají o homogenizované měsíční a sezonní teploty vzduchu měřené na stanici Praha-Klementinum a o rekonstruované řady měsíčních a sezonních teplot vzduchu střední Evropy a řady sezonních srážkových úhrno̊ českých zemí (Česka) v období 1775-2007 (rekonstrukce jsou odvozené z dokumentárních údajů a z meteorologických měření). Dokumentární údaje jsou dále využity pro popis jevů následujících po obou erupcích. V případě erupce Lakagígaru byly v následujících letních měsících roku 1783 pozorovány ve střední Evropě zvláštní projevy počasí v podobě „suché mlhy“ (zákalu), silných bouřek (většinou bez deště) a výrazných optických jevů. Následně se projevily významné záporné teplotní anomálie (tj. studená období) v zimě 1783/84, na jaře roku 1785 a v létě a na podzim roku 1786 (obr. 1-2, tab. 1). Erupce Tambory, jako jedné z největších známých erupcí, nebyla provázena zvláštními povětrnostními jevy, ale následovalo po ní extrémně studené léto roku 1816, kvưli němuž se pro tento rok vžil název „rok bez léta”. Spolu s předchozím deštivým létem roku 1815 a podzimem téhož roku tak 
po sobě následovaly dva roky se špatnou úrodou a výrazným nárůstem cen obilovin, kulminujícím v roce 1817 (obr. 3), což se negativně projevilo ve společenských dopadech (nedostatek chleba, bída, hlad, bankroty, tuláctví). Z dalších výrazných událostí lze uvést povodně v únoru 1784, dubnu 1785 a srpnu 1786 v letech po erupci Lakagígaru a povodně v srpnu 1815 a březnu 1817, stejně jako pět sesuvů v severozápadních Čechách v roce 1817 po erupci Tambory. Zatímco extrémní projevy počasí po erupci Lakagígaru byly dány např. do souvislosti se zemětřesením a teprve později s vulkanickou činností na Islandu, série studených lét od roku 1812, mezi něž se zařadila i léta po erupci Tambory, byla nejdříve dávána do možné souvislosti s výskytem Flaugerguesovy komety v září roku 1811, se změnami v počtu slunečních skvrn či s procesem dlouhodobého ochlazování Země. Teprve po extrémně chladném dubnu 1817 se začala uvádět vedle zemětřesení i možná spojitost s vulkanickou činnosti (i když ne konkrétně s Tamborou). Z porovnání efektů spojených s oběma studovanými erupcemi vyplynulo, že povětrnostní a klimatologické dopady erupce Lakagígaru byly v českých zemích daleko výraznější než v případě Tambory, která se ale zase projevila významnějšími důsledky v ekonomicko-společenských dopadech. Získané poznatky vhodně doplňují z regionálního hlediska rozsáhlou literaturu věnovanou problematice obou erupcí v evropském i širším kontextu.

Obr. 1 Kombinace sezonních teplotních anomálií v Praze-Klementinu a ve střední Evropě a sezonních anomálií srážek v českých zemích v letech 1783-1786 a 1815-1818 (referenční období 1961-1990; Wi - prosinec-únor , Sp - březen-květen, Su - červen-srpen, Au - zář́í-listopad).

Obr. 2 Kombinace měsíčních teplotních anomálií (referenční období 1961-1990) v Praze-Klementinu a ve střední Evropě v letech 1783-1785 a 1815-1817.

Obr. 3 Kombinace kolísání cen čtyř hlavních obilovin (pšenice, žito, ječmen, oves) v letech 1779-1788 a 1811-1820: a - Praha (údaje podle Schebka 1873), Litoměřice pro oves (zlatý / 61,49 l) - údaje jen do roku 1817 podle Tlapáka (1977); b - Brno (groše) - údaje podle Brázdila, Durdákové (2000), Morava (zlatý/hl) - údaje podle Alberta (1964).

\section{ACKNOWLEDGEMENTS}

The authors acknowledge the financial support of the Czech Science Foundation for project no. 13-19831S. RB, LR and LD also received funding from The Ministry of Education, Youth and Sport of the Czech Republic within the National Sustainability Program I (NPU I), grant number LO1415. Tony Long (Svinošice) helped work up the English. 